\title{
Regulation of angiotensin II type 2 receptor gene expression in the adrenal medulla by acute and repeated immobilization stress
}

\author{
Regina Nostramo, Andrej Tillinger, Juan M Saavedra ${ }^{1}$, Ashok Kumar ${ }^{2,+}$, Varunkumar Pandey ${ }^{2,+}$, \\ Lidia Serova, Richard Kvetnansky ${ }^{3}$ and Esther L Sabban \\ Department of Biochemistry and Molecular Biology, New York Medical College, Valhalla, New York 10595, USA \\ ${ }^{1}$ Section of Pharmacology, DIRP, National Institute of Mental Health, NIH, Bethesda, Maryland 20892, USA \\ ${ }^{2}$ Department of Pathology, New York Medical College, Valhalla, New York 10595, USA \\ ${ }^{3}$ Institute of Experimental Endocrinology, Slovak Academy of Sciences, Bratislava, Slovakia \\ (Correspondence should be addressed to E L Sabban; Email: esther_sabban@nymc.edu) \\ ${ }^{\dagger}$ (A Kumar and V Pandey are now at Department of Physiology and Pharmacology, University of Toledo College of Medicine, Toledo, Ohio, USA)
}

\begin{abstract}
While the renin-angiotensin system is important for adrenomedullary responses to stress, the involvement of specific angiotensin II (Ang II) receptor subtypes is unclear. We examined gene expression changes of angiotensin II type $1 \mathrm{~A}\left(\mathrm{AT}_{1 \mathrm{~A}}\right)$ and type $2\left(\mathrm{AT}_{2}\right)$ receptors in rat adrenal medulla in response to immobilization stress (IMO). $\mathrm{AT}_{2}$ receptor mRNA levels decreased immediately after a single 2-h IMO. Repeated IMO also decreased $\mathrm{AT}_{2}$ receptor mRNA levels, but the decline was more transient. $\mathrm{AT}_{1 \mathrm{~A}}$ receptor mRNA levels were unaltered with either single or repeated IMO, although binding was increased following repeated IMO. These effects of stress on Ang II receptor expression may alter catecholamine biosynthesis, as tyrosine hydroxylase and dopamine $\beta$-hydroxylase mRNA levels in PC12 cells are decreased with Ang II treatment in the presence of $\mathrm{ZD7155}$ ( $\mathrm{AT}_{1}$ receptor antagonist) or with CGP42112 ( $\mathrm{AT}_{2}$ receptor agonist) treatment. Involvement
\end{abstract}

of stress-triggered activation of the hypothalamic-pituitaryadrenocortical or sympathoadrenal axis in $\mathrm{AT}_{2}$ receptor downregulation was examined. Cultured cells treated with the synthetic glucocorticoid dexamethasone displayed a transcriptionally mediated decrease in $\mathrm{AT}_{2}$ receptor mRNA levels. However, glucocorticoids are not required for the immediate stress-triggered decrease in $\mathrm{AT}_{2}$ receptor gene expression, as demonstrated in corticotropin-releasing hormone knockout $(\mathrm{Crh} \mathrm{KO})$ mice and hypophysectomized rats, although they can regulate basal gene expression. cAMP and pituitary adenylate cyclase-activating polypeptide also reduced $\mathrm{AT}_{2}$ receptor gene expression and may mediate this response. Overall, the effects of stress on adrenomedullary $\mathrm{AT}_{1 \mathrm{~A}}$ and $\mathrm{AT}_{2}$ receptor expression may contribute to allostatic changes, such as regulation of catecholamine biosynthesis.

Journal of Endocrinology (2012) 215, 291-301

\section{Introduction}

The response of an organism to acute stress is necessary for survival. However, when stress is prolonged or repeated, the response is not only adaptive but also becomes maladaptive. With repeated exposure to stress, there is an increase in allostatic load (McEwen \& Seeman 1999, McEwen 2007). As a result, stress is a major contributor to the development of cardiovascular disorders and neuropsychiatric illnesses and can also adversely influence the progression of chronic diseases, such as diabetes and cancer (reviewed in McEwen (1998) and Chrousos (2009)).

The physiological responses to stress involve multiple systems. The activation of the hypothalamic-pituitaryadrenocortical (HPA) axis and the catecholaminergic sympathoneural and sympathoadrenal systems is key neuroendocrine responses to stress (reviewed in Kvetnansky et al. (2009)). The renin-angiotensin system (RAS), which is known for regulating blood pressure and fluid and electrolyte balance, also plays an important role in the stress response (reviewed in Saavedra et al. (2011) and Saavedra (2012)). Levels of plasma renin as well as circulating and adrenal angiotensin II (Ang II), the main active component of the RAS, are elevated in response to stress (Jindra \& Kvetnanský 1982, Yang et al. 1993). The RAS likely contributes to the development of stress-related cardiovascular disorders (Saavedra et al. 2011); however, the underlying mechanisms are still unclear.

Ang II is a potent secretagogue that stimulates adrenomedullary norepinephrine and epinephrine release (Feldberg \& Lewis 1964). Accordingly, nephrectomy or treatment with a nonselective Ang II receptor antagonist nearly abrogates catecholamine release from cat adrenal medulla in response to the stress of insulin-induced hypoglycemia 
(Bumpus et al. 1980). Ang II also induces catecholamine biosynthesis by elevating gene expression of the catecholamine biosynthetic enzymes, tyrosine hydroxylase (TH), and phenylethanolamine $\mathrm{N}$-methyltransferase (PNMT) (Stachowiak et al. 1990b). The results may depend on which Ang II receptor subtype is involved.

Ang II binds with equal affinity to two major sites, the angiotensin II type $1\left(\mathrm{AT}_{1}\right)$ and type $2\left(\mathrm{AT}_{2}\right)$ receptors (reviewed in de Gasparo et al. (2000)). In rodents, there are two subtypes of $\mathrm{AT}_{1}$ receptor, the $\mathrm{AT}_{1 \mathrm{~A}}$ and $\mathrm{AT}_{1 \mathrm{~B}}$ receptor, which are pharmacologically indistinguishable but differentially regulated (reviewed in Inagami et al. (1994)). The $\mathrm{AT}_{1}$ receptors mediate virtually all the well-known effects of Ang II, including vasoconstrictive, hypertrophic, proliferative, and pro-fibrotic effects. Although the expression of $\mathrm{AT}_{1}$ receptors in rodent adrenal medulla is very low and limited to only the $\mathrm{AT}_{1 \mathrm{~A}}$ receptor subtype (Leong et al. 2002), there is substantial evidence for a role of $\mathrm{AT}_{1}$ receptors in maintaining basal adrenomedullary catecholamine synthesis and in mediating central and adrenomedullary responses to stress (Armando et al. 2001, 2007, Leong et al. 2002, Jezova et al. 2003).

$\mathrm{AT}_{2}$ receptor activation has been proposed to oppose $\mathrm{AT}_{1}$ receptor-mediated effects and is associated with vasodilation; nitric oxide release; and anti-hypertrophic, anti-proliferative, and anti-fibrotic effects (reviewed in de Gasparo et al. (2000)). Multiple in vivo studies using genetically altered animals or selective pharmacological agents suggest tissue protective properties of the $\mathrm{AT}_{2}$ receptor subtype in a number of disease states (reviewed in Jones et al. (2008)). Unlike the $\mathrm{AT}_{1}$ receptor, the $\mathrm{AT}_{2}$ receptor is not very abundant in adult tissues, except for the adrenal gland where it is highly expressed in the zona glomerulosa and medulla (Israel et al. 1995).

While Ang II elevates $T H$ gene expression in primary cultures of bovine adrenomedullary cells (Stachowiak et al. $1990 b)$, more recently it was shown that activation of the $\mathrm{AT}_{2}$ receptor inhibits catecholamine synthesis and $\mathrm{TH}$ expression and activity in porcine adrenomedullary chromaffin cells (Takekoshi et al. 2000, 2002). $\mathrm{AT}_{2}$ receptor gene-deficient mice show elevated adrenomedullary $T h$ and $\mathrm{AT}_{1}$ receptor mRNA levels, norepinephrine and epinephrine levels, as well as enhanced HPA axis stimulation (Saavedra et al. 2001, Armando et al. 2002). This indicates that the $\mathrm{AT}_{1}$ and $\mathrm{AT}_{2}$ receptors may play opposite roles in the regulation of the adrenomedullary response to stress and that the expression of one receptor type may influence the expression of the other.

The relative expression of $\mathrm{AT}_{1}$ and $\mathrm{AT}_{2}$ receptors is an important modulator of adrenomedullary function. The current study is aimed to better understand the changes in Ang II receptor expression in the adrenal medulla in response to acute and repeated stress. Rats were exposed to immobilization stress (IMO), which is a stress model wherein the response of the adrenomedullary catecholaminergic system to various durations and repetitions of this stressor has been well characterized (Sabban \& Kvetnanský 2001,
Liu et al. 2008). The findings reveal a biphasic response of $\mathrm{AT}_{2}$ receptor gene expression to stress and provide insight into the mechanisms that trigger these dramatic changes.

\section{Materials and methods}

\section{Animals}

All animal experiments were performed in accordance with the NIH Guide for the Care and Use of Laboratory Animals (NIH publication no. 85-23, revised 1996) and were approved by the NYMC Institutional Animal Care and Use Committee (rat experiments) or the Ethical Committee of the Institute of Experimental Endocrinology, Slovak Academy of Sciences (mouse experiments).

Male, Sprague Dawley rats (250-320 g) were obtained from Taconic Farms (Germantown, NY, USA). Male, corticotropin-releasing hormone knockout (Crh KO) mice (C57B1/129SV) and WT mice, age 150-180 days, were bred at the Institute of Experimental Endocrinology, as described previously (Kvetnansky et al. 2006). The Crh KO mouse line was originally a generous gift from Dr Joseph A Majzoub (Harvard Medical School, Department of Endocrinology, Boston, MA, USA). The animals were maintained under controlled conditions $\left(23 \pm 2{ }^{\circ} \mathrm{C}, 12 \mathrm{~h}\right.$ light: $12 \mathrm{~h}$ darkness cycle, lights on from $0600 \mathrm{~h}$ ) with food and water ad libitum.

Hypophysectomized or sham-operated rats (Taconic Farms) were administered saline or $25 \mathrm{mg} / \mathrm{kg}$ per day $(1 \mu \mathrm{l} / \mathrm{h})$ hydrocortisone 21-hemisuccinate, sodium salt crystalline (cortisol; Sigma-Aldrich Corp.) for 7 days via osmotic minipump inserted s.c. in the interscapular area. All hypophysectomized rats received isotonic saline instead of drinking water. Complete removal of the pituitary in hypophysectomized rats was visually confirmed.

\section{Stress}

IMO, a strong noninvasive stress model, was performed as described previously (Nankova et al. 1994, Liu et al. 2008) on a metal board by taping the limbs with surgical tape and restricting the motion of the head exactly as originally described by Kvetnansky \& Mikulaj (1970). Rats were subjected to single or repeated IMO. For single IMO $(1 \times$ IMO), rats were immobilized once for $2 \mathrm{~h}$ and subsequently killed either immediately $(0 \mathrm{~h})$ or $3 \mathrm{~h}$ after termination of the stress. For repeated IMO $(6 \times \mathrm{IMO})$, rats were immobilized for $2 \mathrm{~h}$ daily for 6 consecutive days and killed either immediately $(0 \mathrm{~h})$ or $3 \mathrm{~h}$ after termination of the stress. To elucidate the effect of the last IMO, one group of rats (the adapted control group) was immobilized for all but the last IMO and killed the next day $(5 \times \mathrm{IMO}+24 \mathrm{~h})$. Absolute controls were not exposed to stress. For the hypophysectomy experiment, rats were killed immediately after $1 \times \mathrm{IMO}$, performed on the seventh day of saline, or cortisol treatment. 
Immobilization of WT and Crh $\mathrm{KO}$ mice was performed similarly, with the following modifications. For repeated stress, mice were immobilized for $2 \mathrm{~h}$ daily for 7 consecutive days $(7 \times \mathrm{IMO})$. Consequently, the adapted controls were immobilized for $2 \mathrm{~h}$ daily for 6 consecutive days and killed $24 \mathrm{~h}$ later $(6 \times \mathrm{IMO}+24 \mathrm{~h})$.

In all animal experiments, IMO was performed at the same time of the day (between $0800 \mathrm{~h}$ and noon). Following decapitation, the left and right adrenals were dissected. Subsequently, any cortex tissue adhering to the adrenal medulla was carefully removed. It has been estimated that the isolated medulla is $>90 \%$ pure (Liu et al. 2005). The left and right adrenal medullae from each individual animal were frozen separately in liquid nitrogen and kept at $-80{ }^{\circ} \mathrm{C}$.

\section{Primary cultures of rat adrenal medulla and PC12 cell cultures}

Rat adrenal medullae were isolated as described earlier and collected in cold Hank's Balanced Salt Solution (HBSS; Invitrogen). Subsequently, the medullae were incubated with filtered dissociation solution containing $2.6 \mathrm{mg} / \mathrm{ml}$ collagenase type 1 (Worthington Biochemical Corp., Lakewood, NJ, USA), $0 \cdot 15 \mathrm{mg} / \mathrm{ml}$ hyaluronidase type $1-\mathrm{S}$ (Sigma-Aldrich Corp.), $3 \mathrm{mg} / \mathrm{ml}$ BSA (Fisher Scientific, Pittsburgh, PA, USA), and $20 \mathrm{U}$ DNase (Ambion, Austin, TX, USA) in a $37^{\circ} \mathrm{C}$ water bath for $20 \mathrm{~min}$ with periodic resuspension, followed by $20 \mathrm{~min}$ of continuous resuspension until the medullary tissue was dissociated. The reaction was stopped with cold HBSS and the digested tissue centrifuged at $2000 \mathrm{~g}$ for $3 \mathrm{~min}$ at $4{ }^{\circ} \mathrm{C}$. The pellet was resuspended in DMEM (Invitrogen) supplemented with 10\% fetal bovine serum (FBS) (Gemini Bio-Products, West Sacramento, CA, USA), $5 \%$ horse serum (Gemini Bio-Products), and $50 \mu \mathrm{g} / \mathrm{ml}$ streptomycin with $50 \mathrm{IU} / \mathrm{ml}$ penicillin ( $0.5 \%$; Invitrogen). The cells were plated on collagen-coated 12-well tissue culture plates (BD Biosciences, San Jose, CA, USA) and incubated in a $37^{\circ} \mathrm{C}$ humidified incubator with $5 \% \mathrm{CO}_{2}$ for $1 \mathrm{~h}$ before additional media were added. The media were replaced after $24 \mathrm{~h}$. Cultures were used for treatment between 3 and 4 days after plating.

Rat adrenomedullary-derived PC12 cells were grown in the media described earlier and maintained at $37^{\circ} \mathrm{C}$ in a humidified incubator with $5 \% \mathrm{CO}_{2}$, with media changed every other day, as described previously (Serova et al. 1997). Before treatment, cells were plated at about 50\% density.

\section{Cell culture treatment}

For experiments with dexamethasone, 1 day before treatment, the media were replaced with stripped media containing DMEM supplemented with $10 \%$ charcoalstripped FBS (Sigma-Aldrich), dialyzed horse serum (Gemini Bio-Products), and antibiotics. Cells were treated with $1 \mu \mathrm{M}$ dexamethasone (Sigma-Aldrich), a dose that lies within the ranges typically used in PC12 cells and adrenomedullary primary cultures (Stachowiak et al. 1990a,
McMahon \& Sabban 1992), in 0.01\% ethanol for 3·5-24 h and subsequently harvested for total RNA isolation. To determine the role of transcription, $4 \mu \mathrm{M}$ actinomycin $\mathrm{D}$ (Enzo Life Sciences, Farmingdale, NY, USA), a transcription inhibitor, dissolved in $0 \cdot 04 \%$ DMSO was added to the cells immediately before dexamethasone treatment. In some experiments, cells were treated with dexamethasone alone or in combination with $200 \mu \mathrm{M} 8$-(4-chlorophenylthio)adenosine $3^{\prime}, 5^{\prime}$-cyclic monophosphate sodium salt (CPT-cAMP; SigmaAldrich), a membrane permeable cAMP analog, or with $0 \cdot 01 \mathrm{pM}$ to $1000 \mathrm{nM}$ pituitary adenylate cyclase-activating polypeptide (PACAP) 1-38 (Tocris Bioscience, Minneapolis, MN, USA), dissolved in distilled water. Cells were alternatively treated for $8 \mathrm{~h}$ with the $\mathrm{AT}_{2}$ receptor agonist, CGP42112 (1-1000 nM; Tocris Bioscience), or with $10 \mathrm{nM}$ Ang II (Sigma-Aldrich) following $15 \mathrm{~min}$ pretreatment with the $\mathrm{AT}_{1}$ receptor antagonist, ZD7155 (100 nM; Tocris Bioscience), all dissolved in distilled water. In all experiments, controls were treated with vehicle.

\section{Isolation of $R N A$ and quantification of changes in $m R N A$ levels}

Total RNA was isolated using the RNeasy Plus Mini Kit (Qiagen). Total RNA concentration was then quantitated using the NanoDrop 2000 (Thermo Fisher Scientific, Waltham, MA, USA) and reverse transcribed using the RevertAid First-Strand cDNA Synthesis Kit (Thermo Fisher Scientific) using the oligo-dT primer. For quantitative real-time PCR, $2 \mu \mathrm{l}$ cDNA product was mixed with $12.5 \mu \mathrm{l}$ FastStart Universal SYBR Green Master Rox (Roche) and $1 \mu \mathrm{l}$ of the following primer pairs: rat or mouse Th, dopamine $\beta$-hydroxylase $(D b h), \mathrm{AT}_{1 \mathrm{~A}}$ receptor, $\mathrm{AT}_{2}$ receptor, or Gapdh (all purchased from Qiagen), and analyzed on an ABI7900HT Real Time PCR instrument (Applied Biosystems). Data are normalized to Gapdh mRNA levels and expressed as the relative fold change vs control, calculated using the $\Delta \Delta C_{\mathrm{t}}$ method. Gapdh mRNA levels were not altered by any of the experimental conditions. In earlier experiments, real-time RT-PCR for Th and Dbh was performed on the LightCycler (Roche) as described previously (Sabban et al. 2010, Serova et al. 2011). A standard curve plotted using serial dilutions from $2 \mathrm{ng}$ to $0 \cdot 2 \mathrm{pg}$ cDNA was used for quantification by the Fit Points method. Data are normalized to total RNA.

\section{Autoradiography of Ang II receptor types}

Binding experiments were performed as described previously (Nishimura et al. 2000) using consecutive sections (16 $\mu \mathrm{m}$ thick) from the adrenal gland. Sections were incubated with $0.5 \mathrm{nM}\left[{ }^{125} \mathrm{I}\right]$ Sarcosine ${ }^{1}$-Ang II (Sar ${ }^{1}$-Ang II; ARC, St Louis, MO, USA) to determine total binding. Nonspecific binding was determined by incubation as earlier in the presence of $5 \times 10^{-6} \mathrm{M}$ unlabeled Ang II. The binding of $\left[{ }^{125} \mathrm{I}\right] \mathrm{Sar}^{1}$-Ang II to $\mathrm{AT}_{1}$ receptors was determined by incubation with $0.5 \mathrm{nM}\left[{ }^{125} \mathrm{I}\right] \mathrm{Sar}^{1}-$ Ang II in the presence of 
$10^{-5} \mathrm{M}$ of the selective $\mathrm{AT}_{1}$ receptor antagonist losartan (DuPont Merck). The binding of $\left.{ }^{125} \mathrm{I}\right] \mathrm{Sar}^{1}-\mathrm{Ang}$ II to $\mathrm{AT}_{2}$ receptors was determined by incubation with $0.5 \mathrm{nM}$ $\left[{ }^{125} \mathrm{I}\right] \mathrm{Sar}^{1}$-Ang II in the presence of $1 \mu \mathrm{M}$ of the selective $\mathrm{AT}_{2}$ receptor ligand $\mathrm{PD}$ 123319. $\mathrm{AT}_{1}$ or $\mathrm{AT}_{2}$ receptor binding was the binding selectively displaced by losartan or PD 123319 respectively.

\section{Statistical analysis}

All data are expressed as mean \pm s.E.M., unless otherwise noted, with $n=5-8$ per group for animal experiments, $n=4-6$ per group for experiments in PC12 cells, and $n=3$ per group for experiments in primary cultures. Differences were analyzed by Student's $t$-test (if only two groups) or ANOVA followed by Bonferroni's post hoc analysis (if more than two groups) using GraphPad Prism 4 Software (GraphPad Software, Inc., La Jolla, CA, USA). A value of $P \leq 0 \cdot 05$ was considered significant.

\section{Results}

Effect of single and repeated immobilization stress on $A T_{1 A}$ and $A T_{2}$ receptor expression in the adrenal medulla

The stress-triggered changes in $\mathrm{AT}_{1 \mathrm{~A}}$ and $\mathrm{AT}_{2}$ receptor mRNA levels in rat adrenal medulla were first examined. Rats were exposed to the strong stress of immobilization once or repeatedly for up to 6 days as shown in Fig. 1A. The changes in mRNA levels were determined immediately and $3 \mathrm{~h}$ after the final immobilization, chosen based on optimal times for stress-triggered elevations of Th and Pnmt mRNA levels in the adrenal medulla (McMahon et al. 1992, Nankova et al. 1994). There were no significant changes in $\mathrm{AT}_{1 \mathrm{~A}}$ receptor mRNA levels at any of these time points (Fig. 1B).

By contrast, gene expression of the $\mathrm{AT}_{2}$ receptor was profoundly altered by the stress and displayed a biphasic effect. Levels of $\mathrm{AT}_{2}$ receptor mRNA decreased by about $70 \%$ immediately and $90 \% 3 \mathrm{~h}$ after exposure to a single $2 \mathrm{~h}$ IMO (Fig. 1C). In the adapted controls, killed $24 \mathrm{~h}$ after the fifth consecutive daily IMO (i.e. on the sixth day), $\mathrm{AT}_{2}$ receptor mRNA levels were elevated by $65 \%$, compared with unstressed absolute controls. However, exposure of these animals to an additional immobilization (sixth daily IMO) also markedly lowered $\mathrm{AT}_{2}$ receptor mRNA levels to about $50 \%$ of unstressed control levels. Moreover, the reduction was more transient than with the first IMO and did not continue to decline $3 \mathrm{~h}$ afterward.

Next, we examined the effects of IMO on $\mathrm{AT}_{1}$ and $\mathrm{AT}_{2}$ receptor expression using a radioligand binding assay. Three hours after exposure to $1 \times \mathrm{IMO}$, there was no change in $\mathrm{AT}_{1}$ receptor binding and a tendency toward reduced $\mathrm{AT}_{2}$ receptor binding (Fig. 2). However, $3 \mathrm{~h}$ after $6 \times \mathrm{IMO}$, there was an $\sim 50 \%$ increase in both $\mathrm{AT}_{1}$ and $\mathrm{AT}_{2}$ receptor binding.

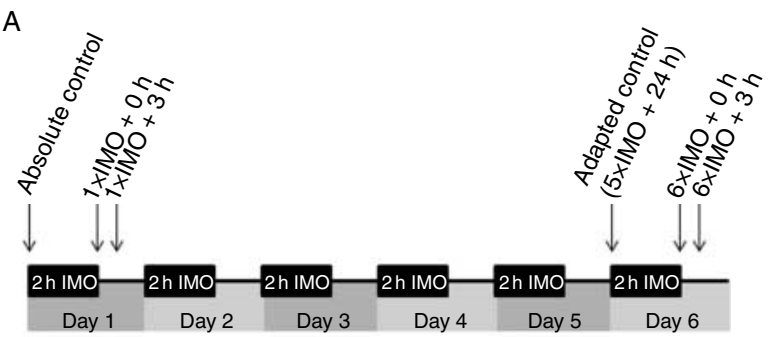

B

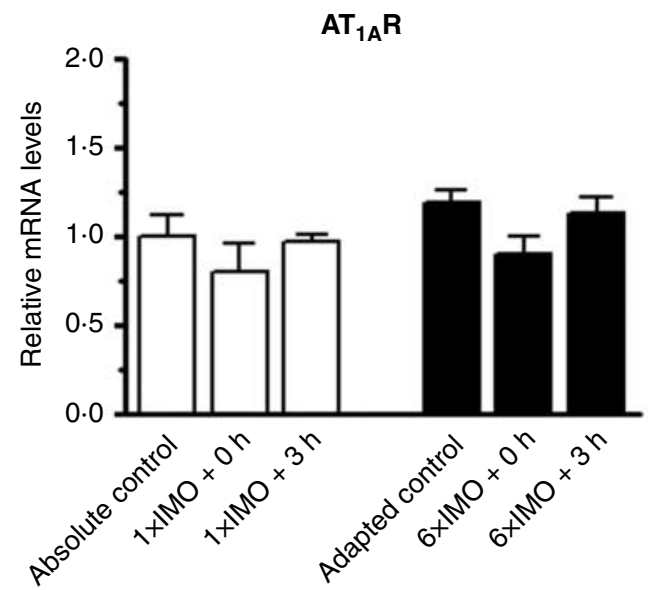

C

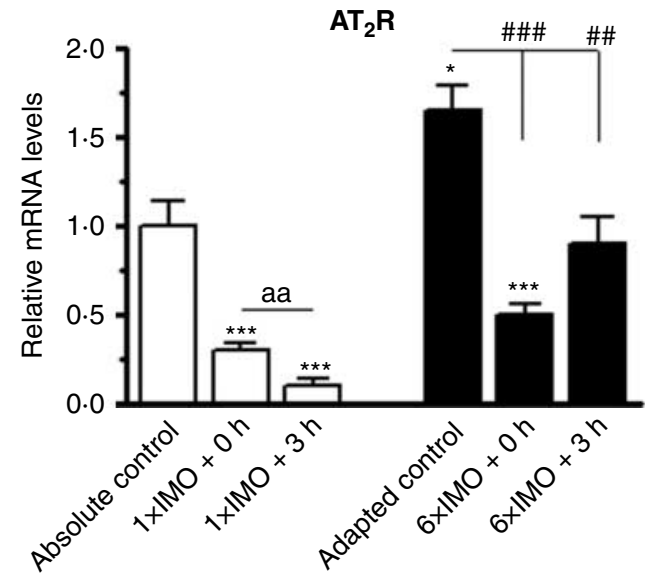

Figure 1 Time course of $\mathrm{AT}_{1 \mathrm{~A}}$ and $\mathrm{AT}_{2}$ receptor gene expression changes in the adrenal medulla in response to single and repeated IMO. (A) Rats were exposed to IMO for $2 \mathrm{~h}$ once $(1 \times)$ or daily for 6 consecutive days $(6 \times)$ and then killed either immediately $(\mathrm{IMO}+0 \mathrm{~h})$ or $3 \mathrm{~h}$ after the final $\mathrm{IMO}(\mathrm{IMO}+3 \mathrm{~h})$. The adapted control group was exposed to $5 \times \mathrm{IMO}$, then killed on the sixth day $(5 \times \mathrm{IMO}+24 \mathrm{~h})$, representing both the starting point for the sixth $\mathrm{IMO}$ and the sustained effects of repeated IMO. Absolute controls were not exposed to stress. $\mathrm{AT}_{1 \mathrm{~A}}(\mathrm{~B})$ and $\mathrm{AT}_{2}(\mathrm{C})$ receptor mRNA levels were determined in the adrenal medulla by real-time RT-PCR, normalized to Gapdh mRNA levels, and expressed relative to unstressed absolute controls, taken as $1 .{ }^{*} P<0 \cdot 05,{ }^{* * *} P<0 \cdot 001$ vs absolute control; ${ }^{\sharp \#} P<0 \cdot 01,{ }^{\sharp \# \#} P<0 \cdot 001$ vs adapted control; ${ }_{\text {aa }} P<0.01$ vs indicated groups. 


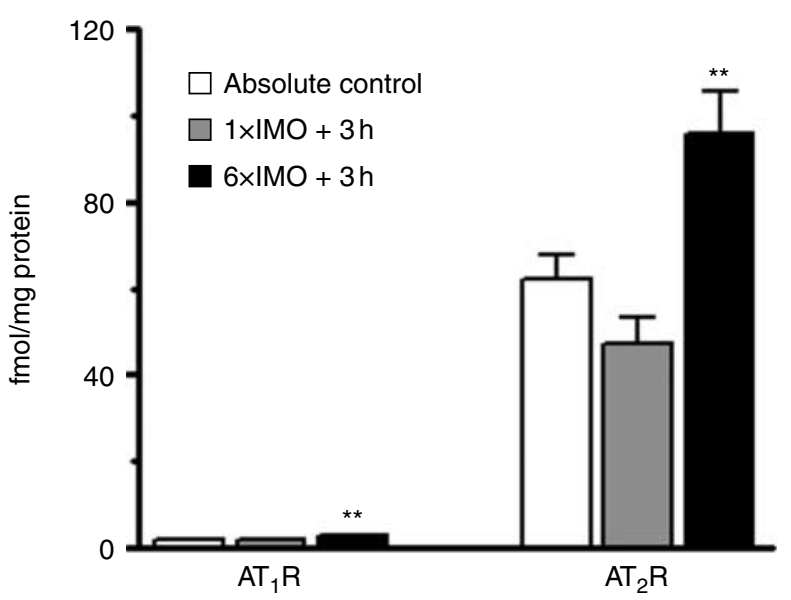

Figure $2 \mathrm{AT}_{1}$ and $\mathrm{AT}_{2}$ receptor binding in the adrenal medulla in response to single and repeated $\mathrm{IMO}$. Adrenal glands were isolated from rats exposed to $2-\mathrm{h}$ IMO once $(1 \times)$ or daily for 6 consecutive days $(6 \times)$ and killed $3 \mathrm{~h}$ after the final IMO. Sections of the adrenal gland were incubated with $0.5 \mathrm{nM}\left[{ }^{125} \mathrm{I}\right] \mathrm{Sar}^{1}$-Ang II and either $10^{-5} \mathrm{M}$ of the selective $\mathrm{AT}_{1}$ receptor antagonist losartan to determine $\mathrm{AT}_{1}$ receptor binding or $1 \mu \mathrm{M}$ of the selective $\mathrm{AT}_{2}$ receptor antagonist $\mathrm{PD} 123319$ to determine $\mathrm{AT}_{2}$ receptor binding. $* * P<0 \cdot 01$ vs absolute control.

Role of the $A T_{1}$ and $A T_{2}$ receptors on catecholamine biosynthetic enzyme gene expression in PC12 cells

As our results suggest that IMO is changing the expression or binding of the $\mathrm{AT}_{1 \mathrm{~A}}$ and $\mathrm{AT}_{2}$ receptors in the adrenal medulla under conditions that are also known to elevate expression of the catecholamine biosynthetic enzymes (reviewed in Sabban \& Kvetnanský (2001)), we examined the relationship between them in adrenomedullary derived PC12 cells. Although the $\mathrm{AT}_{1}$ receptor is expressed at very low levels in PC12 cells, pretreatment with the $\mathrm{AT}_{1}$ receptor antagonist ZD7155 led to a significant reduction of Th and Dbh mRNA levels in response to Ang II, likely by way of $\mathrm{AT}_{2}$ receptor activation (Fig. 3A). This was further studied with the selective $\mathrm{AT}_{2}$ receptor agonist CGP42112. Treatment with CGP42112 for $8 \mathrm{~h}$ led to a dose-dependent decrease in Th $(F=4 \cdot 01 ; P<0 \cdot 05)$ and $D b h(F=14 \cdot 28 ; P<0 \cdot 001)$ mRNA levels (Fig. 3B).

Mechanism of the stress-triggered modulation of $A T_{2}$ receptor gene expression

One of the major responses to stress is the activation of the HPA axis. We speculated that the stress-triggered rise in glucocorticoids may mediate some of the observed changes in $\mathrm{AT}_{2}$ receptor gene expression. Primary rat adrenomedullary cultures were treated with the synthetic glucocorticoid, dexamethasone. Similar to the response with IMO, Th and Dbh mRNA levels were elevated, as expected (Stachowiak et al. 1990a, McMahon \& Sabban 1992). $\mathrm{AT}_{1 \mathrm{~A}}$ receptor mRNA levels were unchanged, while there was a precipitous decline in $\mathrm{AT}_{2}$ receptor mRNA levels (Fig. 4A).
The time course of changes in $T h, D b h$, and $\mathrm{AT}_{2}$ receptor mRNA levels in response to dexamethasone was determined in PC12 cells (Fig. 4B). Cells were treated with dexamethasone for various times up to $24 \mathrm{~h}$. Th and Dbh mRNA levels were elevated as previously reported (Stachowiak et al. 1990a, McMahon \& Sabban 1992). There was a time-dependent decrease in $\mathrm{AT}_{2}$ receptor mRNA levels $(F=96 \cdot 29$; $P<0 \cdot 001$ ) from $\sim 80$ to $10 \%$ of basal levels from 3.5 to $24 \mathrm{~h}$ with dexamethasone. This response is mediated largely at the transcriptional level, as 8-h treatment with dexamethasone in the presence of $4 \mu \mathrm{M}$ of the transcription inhibitor, actinomycin $\mathrm{D}$, abolished the decrease in $\mathrm{AT}_{2}$ receptor mRNA levels (Fig. 4C).

To further understand the importance of glucocorticoids in vivo, we analyzed the changes in $\mathrm{AT}_{2}$ receptor mRNA levels in the adrenal medulla of $\mathrm{Crh} \mathrm{KO}$ mice following single $(1 \times)$ or repeated $(7 \times)$ IMO (Fig. $5 \mathrm{~A})$. These mice are
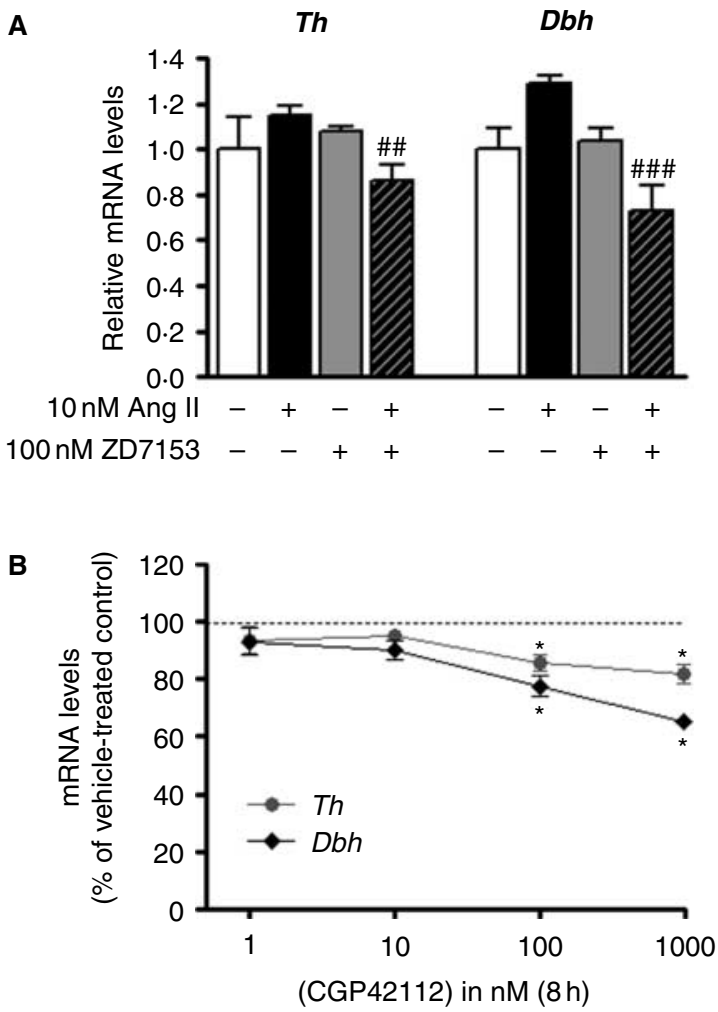

Figure $3 \mathrm{AT}_{1}$ and $\mathrm{AT}_{2}$ receptor-mediated regulation of $T h$ and $D b h$ gene expression in PC12 cells. (A) PC12 cells were pretreated with $100 \mathrm{nM}$ ZD7155 (AT 1 receptor antagonist) for $15 \mathrm{~min}$, then treated with $10 \mathrm{nM}$ Ang II for $8 \mathrm{~h}$. Subsequently, Th and Dbh mRNA levels were determined by real-time RT-PCR, normalized to total RNA levels, and expressed relative to control, taken as $1 .{ }^{\#} P<0 \cdot 01$, $\# \# P<0 \cdot 001$ vs Ang II-treated group. (B) PC12 cells were treated with 1-1000 nM CGP42112 (AT 2 receptor agonist) for $8 \mathrm{~h}$. Subsequently, Th and Dbh mRNA levels were determined by real-time RT-PCR, normalized to total RNA levels, and expressed as the percentage of control levels (dotted line), taken as $100 \%$. $* P<0 \cdot 05$ vs control. 


\section{A Cultured rat adrenomedullary cells}

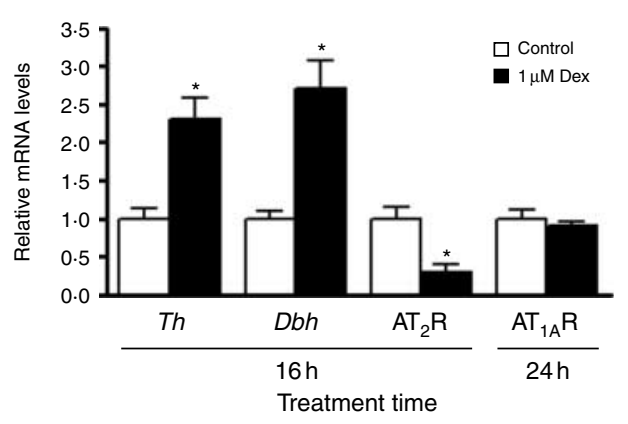

PC12 cells
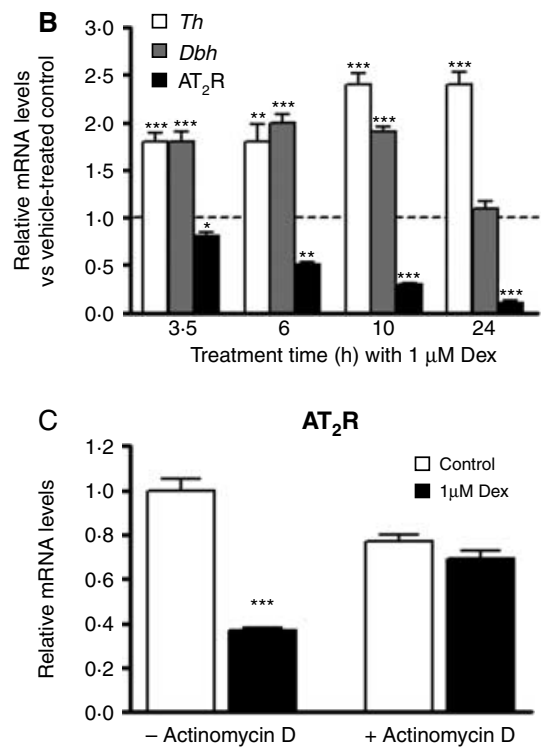

Figure 4 Effect of dexamethasone on $\mathrm{AT}_{1 \mathrm{~A}}$ and $\mathrm{AT}_{2}$ receptor gene expression in rat adrenal medulla primary cultures and PC12 cells. Rat adrenal medulla primary cultures (A) or PC12 cells (B) were treated with $1 \mu \mathrm{M}$ dexamethasone (Dex) or vehicle (control) for up to $24 \mathrm{~h}$. Subsequently, total RNA was isolated and Th, Dbh, $\mathrm{AT}_{2}$ receptor, or $\mathrm{AT}_{1 \mathrm{~A}}$ receptor $\mathrm{mRNA}$ levels were determined by realtime RT-PCR. Data are normalized to Gapdh mRNA levels and expressed relative to their respective time-matched control, taken as 1 , indicated as a dotted line in (B). (C) PC12 cells were treated for $8 \mathrm{~h}$ with $1 \mu \mathrm{M}$ Dex in the presence or absence of $4 \mu \mathrm{M}$ actinomycin $\mathrm{D}$ (transcription inhibitor). Total $\mathrm{RNA}$ was isolated and $\mathrm{AT}_{2}$ receptor mRNA levels were determined by real-time RT-PCR. Data are normalized to Gapdh mRNA levels and expressed relative to vehicle-treated control, taken as $1 .{ }^{*} P<0 \cdot 05,{ }^{* *} P<0 \cdot 01$, $* * * P<0 \cdot 001$ vs vehicle-treated control.

unable to synthesize $\mathrm{CRH}$ and do not display the large elevation in plasma ACTH and corticosterone in response to stress (Muglia et al. 2000, Kvetnansky et al. 2006). The reduction in $\mathrm{AT}_{2}$ receptor mRNA levels in the WT mice in response to single or repeated IMO (Fig. 5B) was similar to the changes observed in rats (Fig. 1C). A comparison between the WT and $C r h$ KO mice demonstrated no difference in basal $\mathrm{AT}_{2}$ receptor mRNA levels in unstressed absolute controls.
Immediately following $1 \times \mathrm{IMO}, \mathrm{AT}_{2}$ receptor mRNA levels were decreased by $\sim 75 \%$ in both the WT and Crh $\mathrm{KO}$ mice, indicating that the rise in glucocorticoids is not essential for $\mathrm{AT}_{2}$ receptor downregulation in the immediate response to acute stress. Similarly, there was a $45-65 \%$ decline in $\mathrm{AT}_{2}$ receptor mRNA levels relative to respective adapted controls immediately after exposure to the seventh IMO in both the WT and the Crh KO mice.

However, in the adapted controls (studied $24 \mathrm{~h}$ after the sixth IMO and not exposed to the seventh IMO), $\mathrm{AT}_{2}$ receptor mRNA levels were elevated by approximately twofold in the Crh KO mice but not significantly in the WT mice, relative to respective genotype-specific unstressed absolute controls. This suggests that the stress-triggered elevation in glucocorticoids may attenuate upregulation of $\mathrm{AT}_{2}$ receptor gene expression in the prolonged response to repeated stress exposure.

We further analyzed the role of glucocorticoids in the regulation of $\mathrm{AT}_{2}$ receptor gene expression in hypophysectomized rats under basal conditions and in response to $1 \times \mathrm{IMO}$. Compared with sham-operated controls, $\mathrm{AT}_{2}$ receptor mRNA levels were increased by approximately threefold in hypophysectomized rats (Fig. 6). This induction is reversed by cortisol supplementation, indicating that glucocorticoids are potent negative regulators of $\mathrm{AT}_{2}$ receptor gene expression under basal conditions. Immediately following $1 \times \mathrm{IMO}$, however, $\mathrm{AT}_{2}$ receptor mRNA levels are significantly reduced in both sham-operated and hypophysectomized rats compared with respective unstressed controls. These data provide further evidence that glucocorticoids are not essential for the decrease in $\mathrm{AT}_{2}$ receptor mRNA levels immediately following IMO.

As the stress-triggered reduction in adrenomedullary $\mathrm{AT}_{2}$ receptor mRNA levels was observed in $\mathrm{Crh} \mathrm{KO}$ mice and hypophysectomized rats, a non-HPA mechanism likely mediates this response. Stress-triggered activation of the splanchnic nerve markedly increases nicotinic cholinergic stimulation of the adrenal medulla as well as release of PACAP, which can elevate cAMP levels in chromaffin cells. Therefore, we looked at the response of $\mathrm{AT}_{2}$ receptor gene expression to combined elevations in both cAMP and glucocorticoids. PC12 cells were treated for $24 \mathrm{~h}$ with $200 \mu \mathrm{M}$ CPT-cAMP, a membrane permeable cAMP analog, alone or together with $1 \mu \mathrm{M}$ dexamethasone. $\mathrm{AT}_{2}$ receptor mRNA levels were decreased by approximately three orders of magnitude in response to CPT-cAMP (Fig. 7A). The combined treatment of CPT-cAMP and dexamethasone lowered $\mathrm{AT}_{2}$ receptor mRNA levels to a similar extent. The response to PACAP was also examined. Treatment of PC12 cells for $7 \mathrm{~h}$ with concentrations of $0.01 \mathrm{pM}$ to $1000 \mathrm{nM}$ PACAP $1-38$, the predominant endogenous form, elicited a dose-dependent reduction in $\mathrm{AT}_{2}$ receptor mRNA levels $(F=71 \cdot 13$; $P<0 \cdot 0001)$, while elevating $T h(F=26 \cdot 45 ; P<0 \cdot 0001)$ and Dbh $(F=130 \cdot 40 ; P<0 \cdot 0001)$ mRNA levels (Fig. 7B). A 90\% reduction in $\mathrm{AT}_{2}$ receptor mRNA levels was observed with $1000 \mathrm{nM}$ PACAP 1-38, the highest concentration 

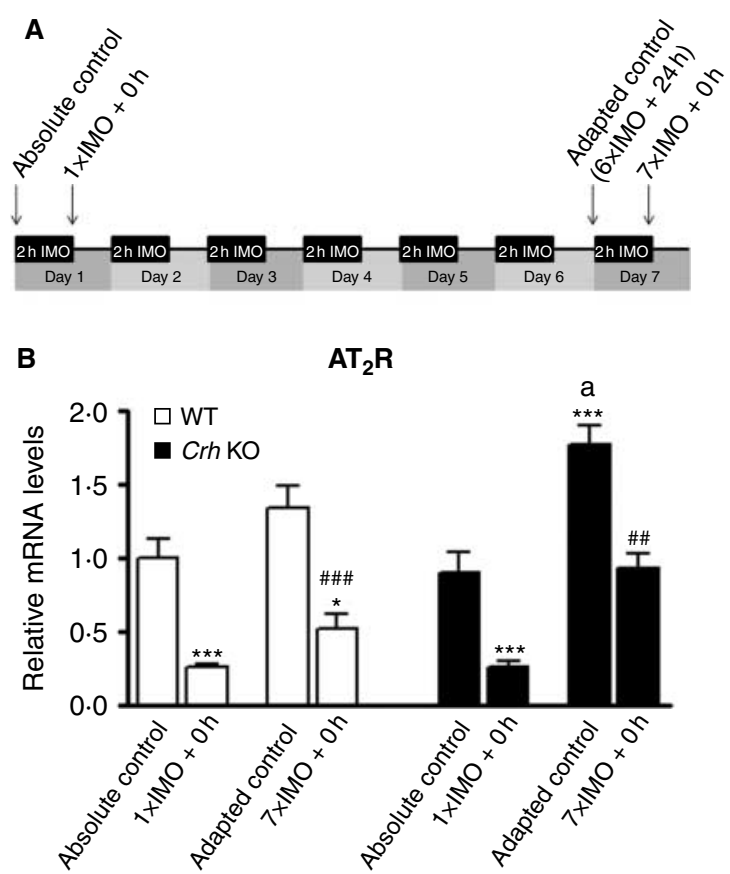

Figure 5 Effects of single and repeated immobilization stress on $\mathrm{AT}_{2}$ receptor gene expression in the adrenal medulla of WT and $\mathrm{Crh}$ KO mice. (A) WT and Crh KO mice were exposed to IMO for $2 \mathrm{~h}$ once $(1 \times)$ or daily for 7 consecutive days $(7 \times)$ and then killed immediately after the final IMO (IMO $+0 \mathrm{~h})$. The adapted control group was exposed to $6 \times \mathrm{IMO}$, then killed on the seventh day $(6 \times \mathrm{IMO}+24 \mathrm{~h})$, representing both the starting point for the seventh IMO and the sustained effects of repeated IMO. Absolute controls were not exposed to stress. (B) $\mathrm{AT}_{2}$ receptor mRNA levels in the adrenal medulla of WT or Crh KO mice were determined by realtime RT-PCR, normalized to Gapdh mRNA levels, and expressed relative to WT absolute control levels, taken as $1 .{ }^{*} P<0 \cdot 05$, ${ }^{* * *} P<0.001$ vs genotype-matched absolute control; ${ }^{\# \#} P<0 \cdot 01$, $\# \# P<0.001$ vs genotype-matched adapted control; ${ }^{\#} P<0.05$ vs WT adapted control relative to absolute control for the respective genotype.

tested. These results indicate that PACAP-triggered elevation of cAMP could be mediating downregulation of $\mathrm{AT}_{2}$ receptor gene expression immediately and shortly after stress.

\section{Discussion}

This study showed, for the first time, the kinetics of $\mathrm{AT}_{1 \mathrm{~A}}$ and $\mathrm{AT}_{2}$ receptor gene expression changes in the adrenal medulla in response to single and repeated exposure to IMO. $\mathrm{AT}_{1 \mathrm{~A}}$ receptor mRNA levels are unaltered by any of the conditions examined, although binding is increased following repeated IMO. By contrast, $\mathrm{AT}_{2}$ receptor gene expression is especially sensitive to IMO and demonstrated a biphasic response. Immediately following either single or repeated $\mathrm{IMO}, \mathrm{AT}_{2}$ receptor gene expression is rapidly downregulated. However, after $24 \mathrm{~h}$ recovery from repeated exposures to the stress, $\mathrm{AT}_{2}$ receptor gene expression is higher than in unstressed absolute controls (as seen in adapted controls). $\mathrm{AT}_{2}$ receptor binding is actually elevated $3 \mathrm{~h}$ after $6 \times \mathrm{IMO}$, similar to the $\mathrm{AT}_{1 \mathrm{~A}}$ receptor. Together, these findings suggest that IMO alters the ratio of $\mathrm{AT}_{1 \mathrm{~A}}$ and $\mathrm{AT}_{2}$ receptor subtypes, which can affect catecholamine biosynthesis. Indeed, IMO changes the expression or binding of these receptors at a time when expression of the catecholamine biosynthetic enzymes is elevated (reviewed in Sabban \& Kvetnanský (2001)). A role of $\mathrm{AT}_{1}$ receptors is supported by the finding that $T h$ and $D b h$ mRNA levels in PC12 cells are decreased by Ang II treatment in the presence of ZD7155 (an $\mathrm{AT}_{1}$ receptor antagonist). Conversely, treatment with the $\mathrm{AT}_{2}$ receptor agonist CGP42112 decreased Th and Dbh mRNA levels. Experiments to determine the mechanism by which stress alters $\mathrm{AT}_{2}$ receptor gene expression show that glucocorticoids are able to lower $\mathrm{AT}_{2}$ receptor mRNA levels in a transcriptionally mediated pathway. In this regard, glucocorticoids can act as negative regulators of basal adrenomedullary $\mathrm{AT}_{2}$ receptor gene expression and appear to attenuate the upregulation of $\mathrm{AT}_{2}$ receptor gene expression in the prolonged response to repeated stress. However, they are not essential for the rapid drop in $\mathrm{AT}_{2}$ receptor gene expression in the immediate response to stress. Instead, this study suggests a possible role of PACAP and cAMP in the regulation of $\mathrm{AT}_{2}$ receptor gene expression.

\section{Stress-triggered changes in Ang II receptor expression in the adrenal medulla}

$\mathrm{AT}_{1}$ and $\mathrm{AT}_{2}$ receptor gene and protein expression were studied using real-time RT-PCR and receptor binding,

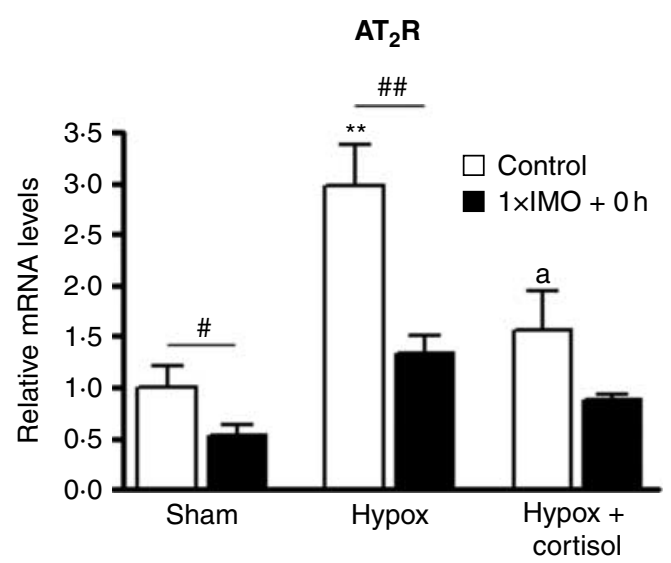

Figure 6 Regulation of $\mathrm{AT}_{2}$ receptor gene expression in the adrenal medulla of hypophysectomized rats under basal conditions and in response to single immobilization stress. Sham-operated or hypophysectomized (Hypox) rats, supplemented with or without cortisol, were exposed to a single 2 -h immobilization stress and killed immediately $(1 \times \mathrm{IMO}+0 \mathrm{~h})$. $\mathrm{AT}_{2}$ receptor mRNA levels were determined in the adrenal medulla by real-time RT-PCR, normalized to Gapdh mRNA levels, and expressed relative to sham-operated unstressed controls, taken as $1 .{ }^{* *} P<0 \cdot 01$ vs sham-operated unstressed control; ${ }^{a} P<0.05$ vs Hypox unstressed control; ${ }^{\#} P<0 \cdot 05,{ }^{\#} P<0 \cdot 01$ vs indicated groups. 

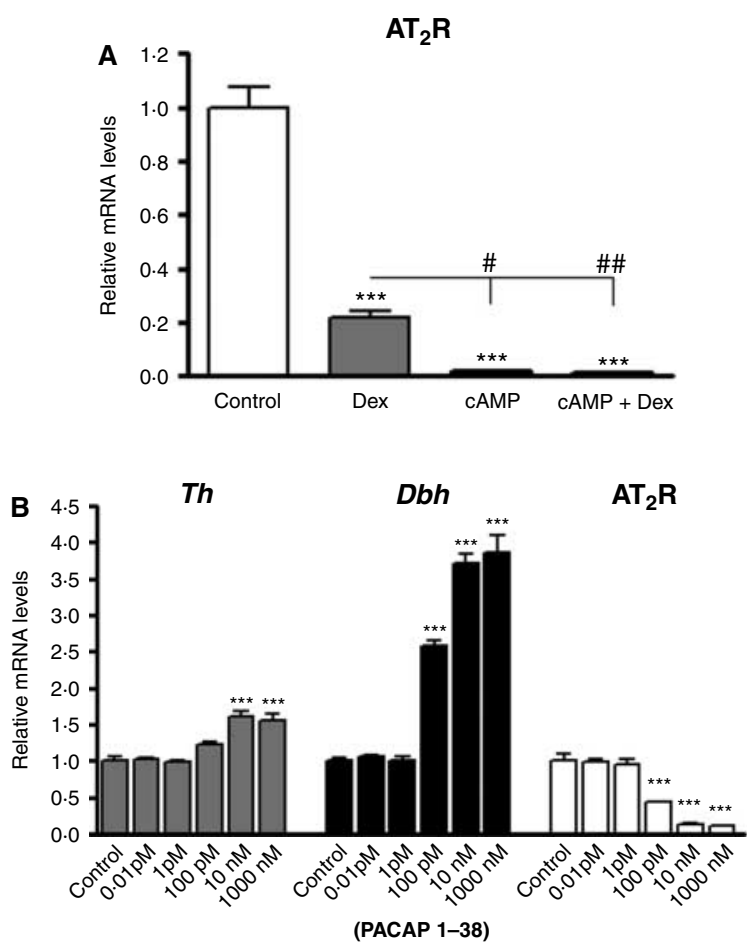

Figure 7 Effects of $\mathrm{CAMP}$ and PACAP on $\mathrm{AT}_{2}$ receptor gene expression in PC12 cells. (A) PC12 cells were treated for $24 \mathrm{~h}$ with $1 \mu \mathrm{M}$ dexamethasone (Dex) in the presence or absence of $200 \mu$ M CPT-cAMP (cAMP), a membrane-permeable cAMP analog. Subsequently, total RNA was isolated and $\mathrm{AT}_{2}$ receptor $\mathrm{mRNA}$ levels were determined by real-time RT-PCR. Data are normalized to Gapdh mRNA levels and expressed relative to vehicle-treated control, taken as $1 .{ }^{* * *} P<0 \cdot 001$ vs control; ${ }^{\#} P<0 \cdot 05,{ }^{\# \#} P<0 \cdot 01$ vs Dex-treated group. (B) PC12 cells were treated for $7 \mathrm{~h}$ with $0.01 \mathrm{pM}$ to $1000 \mathrm{nM}$ PACAP 1-38. Subsequently, total RNA was isolated and $T h, D b h$, and $\mathrm{AT}_{2}$ receptor $\mathrm{mRNA}$ levels were determined by real-time RT-PCR. Data are normalized to Gapdh mRNA levels and expressed relative to vehicle-treated control, taken as $1 .{ }^{* * *} P<0 \cdot 001$ vs control.

as the commercially available antibodies for the $\mathrm{AT}_{1}$ (Benicky et al. 2012) and $\mathrm{AT}_{2}$ receptors ( $\mathrm{R}$ Nostramo, E L Sabban, J M Saavedra 2012, unpublished observations) are not specific. The downregulation of $\mathrm{AT}_{2}$ receptor $\mathrm{mRNA}$ levels to as low as $1 / 10$ of basal levels, observed $3 \mathrm{~h}$ after $1 \times \mathrm{IMO}$, is also reflected by a tendency for reduced $\mathrm{AT}_{2}$ receptor binding. The decline in $\mathrm{AT}_{2}$ receptor binding with $1 \times \mathrm{IMO}$ is less pronounced than the changes in mRNA levels. This is probably due to the time point examined ( $3 \mathrm{~h}$ after the IMO), as the reduction in mRNA levels is likely to precede the changes in protein expression. Conversely, neither $\mathrm{AT}_{1 \mathrm{~A}}$ receptor mRNA levels nor $\mathrm{AT}_{1}$ receptor binding is altered by $1 \times$ IMO. Therefore, acute exposure to IMO may trigger an increase in the relative expression of $\mathrm{AT}_{1 \mathrm{~A}}$ to $\mathrm{AT}_{2}$ receptors.

The changes in Ang II receptor expression following repeated stress exposure are different. With repeated IMO, there is a drop in $\mathrm{AT}_{2}$ receptor mRNA levels immediately after the stress, yet at the time examined ( $3 \mathrm{~h}$ afterwards) binding is elevated compared with unstressed absolute controls. This could reflect 1) the decrease in $\mathrm{AT}_{2}$ receptor mRNA levels from a higher starting point before the sixth IMO (adapted controls) than before the first IMO (absolute controls) and 2) the more transient reduction in $\mathrm{AT}_{2}$ receptor mRNA levels after repeated compared with single IMO. $\mathrm{AT}_{1}$ receptor binding is also elevated $3 \mathrm{~h}$ after $6 \times \mathrm{IMO}$, although there is no change in mRNA levels. This could reflect increased receptor stability, decreased recycling, or altered dimerization patterns without alterations in receptor gene transcription.

The changes in adrenomedullary $\mathrm{AT}_{1 \mathrm{~A}}$ and $\mathrm{AT}_{2}$ receptor mRNA levels were previously examined immediately following exposure of rats to restraint stress using in situ hybridization and ligand binding assays (Leong et al. 2002). Similar to our results with IMO using quantitative RT-PCR, $\mathrm{AT}_{2}$ receptor mRNA levels decreased immediately following a single 2-h restraint. In contrast to our finding of a transient decline in $\mathrm{AT}_{2}$ receptor mRNA levels with repeated (6 daily) $\mathrm{IMO}, \mathrm{AT}_{2}$ receptor $\mathrm{mRNA}$ did not differ from basal levels immediately following repeated (7 daily) exposures to restraint stress (Leong et al. 2002). Additionally, $\mathrm{AT}_{1}$ receptor binding was unaltered immediately following repeated restraint stress, yet increased $3 \mathrm{~h}$ after repeated immobilization stress. These differences may reflect the decreased severity or more rapid habituation to the milder stress of restraint, compared with immobilization.

Effects of stress-triggered modulation of Ang II receptor expression on adrenomedullary function

The altered expression of $\mathrm{AT}_{1}$ and $\mathrm{AT}_{2}$ receptors likely has important consequences for the adrenomedullary response to stress, and in particular the degree of catecholamine production and release. Previous data support an inhibitory role of the $\mathrm{AT}_{2}$ receptor and a stimulatory role of the $\mathrm{AT}_{1}$ receptor on adrenomedullary catecholamine biosynthesis in response to selective Ang II receptor subtype activation in cultured porcine adrenomedullary chromaffin cells and in mouse adrenal medulla (Takekoshi et al. 2000, 2002, Armando et al. 2002). Through the pharmacological application of the compounds CGP42112 and ZD7155, we found that the $A T_{1}$ and $A T_{2}$ receptors mediate similar converse effects on Th mRNA levels, and for the first time, Dbh mRNA levels in PC12 cells. CGP42112, a partial $\mathrm{AT}_{2}$ receptor agonist, can displace $\mathrm{AT}_{2}$ receptors selectively and with high affinity (Heemskerk \& Saavedra 1995). At the higher concentrations used here, however, it may exert additional effects unrelated to $\mathrm{AT}_{2}$ receptors, as is the case for compound 21 (reviewed in Henrion (2012)). Similarly, ZD7155, a high-affinity $\mathrm{AT}_{1}$ receptor antagonist (Remuzzi et al. 1996), has been used at high concentrations and the results obtained may be in part the consequence of nonselective effects. To completely elucidate the role of $\mathrm{AT}_{2}$ receptors, it will be necessary to develop novel very specific, potent, and selective receptor agonists and antagonists. 
As $\mathrm{AT}_{1}$ receptor expression is very low in PC12 cells (data not shown), the altered response of $T h$ and $D b h$ gene expression to Ang II in the presence of ZD7155 suggests that small changes in the ratio of $\mathrm{AT}_{1 \mathrm{~A}} / \mathrm{AT}_{2}$ receptor expression may have significant effects on catecholamine biosynthesis following receptor activation. We hypothesize that the decrease in $\mathrm{AT}_{2}$ receptor activation in response to acute stress may remove an inhibitory factor in catecholamine production, thus allowing $\mathrm{AT}_{1}$ receptor stimulation by increased circulating and/or locally produced Ang II to increase catecholamine formation. In this regard, adrenal and urinary norepinephrine and epinephrine levels were decreased following isolation stress in rats treated with the $\mathrm{AT}_{1}$ receptor antagonist candesartan (Armando et al. 2001). Conversely, the increase in $\mathrm{AT}_{2}$ receptor gene expression following prolonged exposure to stress (observed in adapted controls) may be a protective mechanism, as $\mathrm{AT}_{2}$ receptor upregulation mediates neuro-, vaso-, and reno-protective effects in numerous pathologies (reviewed in Jones et al. (2008)).

\section{Role of the HPA and sympathoadrenal axes in the down- regulation of $A T_{2}$ receptor gene expression in response to stress}

One of the major responses to stress is the activation of the HPA axis with elevations in plasma ACTH and corticosterone levels. Treatment of rat adrenal medulla primary cultures and PC12 cells with the synthetic glucocorticoid dexamethasone decreases $\mathrm{AT}_{2}$ receptor mRNA levels. In this regard, dexamethasone decreased $\mathrm{AT}_{2}$ receptor transcription and mRNA levels in serum-depleted PC12 cells (Kijima et al. 1995). This response in PC12 cells is progressive and is inhibited by actinomycin $\mathrm{D}$, indicating that it is likely transcriptionally mediated. Accordingly, the promoter of the $\mathrm{AT}_{2}$ receptor is reported to contain a glucocorticoid regulatory motif (Martin \& Elton 1995, Ichiki et al. 1996). Our in vivo data demonstrate that glucocorticoids can act as negative regulators of basal adrenomedullary $\mathrm{AT}_{2}$ receptor gene expression as cortisol supplementation reversed the hypophysectomy-induced increase in $\mathrm{AT}_{2}$ receptor mRNA levels. However, this effect on basal $\mathrm{AT}_{2}$ receptor gene expression was not observed in $\mathrm{Crh} \mathrm{KO}$ mice. This difference may be due to activation of compensatory pathways or strengthening of redundant pathways, the consequences of the life-long $\mathrm{Crh} \mathrm{KO}$.

However, in response to stress, $\mathrm{AT}_{2}$ receptor mRNA levels are decreased in WT and Crh $\mathrm{KO}$ mice. While this suggests that the stress-triggered rise in glucocorticoids is not essential for $\mathrm{AT}_{2}$ receptor downregulation, it does not rule out a role for aldosterone. The absence of $\mathrm{CRH}$ has no effect on levels of plasma aldosterone (Muglia et al. 1995), which is released in response to stress (Stier et al. 2004) and can inhibit adrenomedullary $\mathrm{AT}_{2}$ receptor mRNA levels (Wang et al. 1998). Conversely, hypophysectomy reduces basal plasma aldosterone levels (Rauschkolb et al. 1956, Balment et al. 1986) and probably aldosterone release during stress. As $\mathrm{AT}_{2}$ receptor mRNA levels are decreased following acute stress in sham-operated and hypophysectomized rats, the involvement of aldosterone is unlikely.

Even though glucocorticoids do not appear to be required for the downregulation of $\mathrm{AT}_{2}$ receptor mRNA levels immediately following IMO, the findings suggest that they may attenuate $\mathrm{AT}_{2}$ receptor gene expression in the prolonged response following repeated exposure to stress. Glucocorticoids may dampen the effects mediated by elevated $\mathrm{AT}_{2}$ receptor expression in the long-term response to repeated stress exposure.

Much like the absence of an effect of IMO on adrenomedullary $\mathrm{AT}_{1 \mathrm{~A}}$ receptor mRNA levels, dexamethasone also did not change $\mathrm{AT}_{1 \mathrm{~A}}$ receptor gene expression. This suggests that there may be tissue-specific differences in glucocorticoid-mediated regulation of the $\mathrm{AT}_{1 \mathrm{~A}}$ receptor gene as its promoter contains a glucocorticoid response element and dexamethasone treatment increased promoter activity in rat vascular smooth muscle cells (Guo et al. 1995, Murasawa et al. 1995).

In addition to glucocorticoids, IMO has been shown to activate multiple signaling pathways in the adrenal medulla (reviewed in Kvetnansky et al. (2009)) as well as lead to the induction of growth factors and cytokines (Liu et al. 2008), which are also implicated in the downregulation of $\mathrm{AT}_{2}$ receptor gene expression in PC12 cells (Kijima et al. 1995). Elevated cAMP, by CPT-cAMP, was found to be very effective in lowering $\mathrm{AT}_{2}$ receptor mRNA levels in $\mathrm{PC} 12$ cells, as previously observed in dibutyryl cAMP-treated serum-depleted PC12 cells, which triggered destabilization of $\mathrm{AT}_{2}$ receptor mRNA (Murasawa et al. 1996). After $24 \mathrm{~h}$ treatment with CPT-cAMP, there is almost a complete loss (three orders of magnitude decline) of $\mathrm{AT}_{2}$ receptor mRNA levels, whether in the presence or absence of dexamethasone. Elevated cAMP could be involved in mediating the large reduction in $\mathrm{AT}_{2}$ receptor gene expression with IMO. Stimulation of the adrenal medulla by release of acetylcholine and PACAP from the splanchnic nerve, with subsequent elevations in calcium and cAMP and their signaling pathways, are important in mediating the adrenomedullary response to stress (Hamelink et al. 2002, Kvetnansky et al. 2009, Stroth \& Eiden 2010). Our results show that PACAP decreases $A_{2}$ receptor mRNA levels in PC12 cells and thus may mediate the observed stress-induced changes in $\mathrm{AT}_{2}$ receptor gene expression.

Overall, the changes in $\mathrm{AT}_{1}$ and $\mathrm{AT}_{2}$ receptor expression in the adrenal medulla likely contribute to the regulation of adrenomedullary function in response to stress. The rapid decrease in $\mathrm{AT}_{2}$ receptor expression observed immediately following a single exposure to stress would result in increased $\mathrm{AT}_{1}$ receptor activation, increasing catecholamine biosynthesis, and release to handle the immediate threat to homeostasis. Conversely, upregulation of the $\mathrm{AT}_{2}$ receptor may serve a protective function after prolonged repeated stress exposure. 


\section{Declaration of interest}

The authors declare that there is no conflict of interest that could be perceived as prejudicing the impartiality of the research reported.

\section{Funding}

This work was supported by the American Heart Association (grant no. 10GRNT442001) to E L S and grant nos APVV-0088-10 and VEGA 2/0036/11 to R K.

\section{Acknowledgements}

The authors gratefully acknowledge Enrique Sanchez-Lemus (National Institute of Mental Health, NIH, Bethesda, MD, USA) for assistance with the binding assays and Sudhir Jain and Shreekrishna Maharjan (Department of Pathology, New York Medical College, Valhalla, NY, USA) for assistance with the initial animal experiments.

\section{References}

Armando I, Carranza A, Nishimura Y, Hoe KL, Barontini M, Terrón JA, Falcón-Neri A, Ito T, Juorio AV \& Saavedra JM 2001 Peripheral administration of an angiotensin II AT(1) receptor antagonist decreases the hypothalamic-pituitary-adrenal response to isolation stress. Endocrinology 142 3880-3889. (doi:10.1210/en.142.9.3880)

Armando I, Terrón JA, Falcón-Neri A, Takeshi I, Häuser W, Inagami T \& Saavedra JM 2002 Increased angiotensin II AT(1) receptor expression in paraventricular nucleus and hypothalamic-pituitary-adrenal axis stimulation in $\mathrm{AT}(2)$ receptor gene disrupted mice. Neuroendocrinology 76 137-147. (doi:10.1159/000064525)

Armando I, Volpi S, Aguilera G \& Saavedra JM 2007 Angiotensin II AT1 receptor blockade prevents the hypothalamic corticotropin-releasing factor response to isolation stress. Brain Research 1142 92-99. (doi:10.1016/ j.brainres.2007.01.037)

Balment RJ, Brimble MJ, Forsling ML \& Musabayane CT 1986 The influence of neurohypophysial hormones on renal function in the acutely hypophysectomized rat. Journal of Physiology 381 439-452.

Benicky J, Hafko R, Sanchez-Lemus E, Aguilera G \& Saavedra JM 2012 Six commercially available angiotensin II AT(1) receptor antibodies are non-specific. Cellular and Molecular Neurobiology. In press. (doi:10.1007/ s10571-012-9862-y)

Bumpus MF, Feuerstein G, Gutman Y \& Khosla MC 1980 Renin-angiotensin mediation of adrenal catecholamine secretion induced by hypoglycaemia in the cat. British Journal of Pharmacology 69 201-205. (doi:10.1111/j.1476-5381.1980.tb07891.x)

Chrousos GP 2009 Stress and disorders of the stress system. Nature Reviews. Endocrinology 5 374-381. (doi:10.1038/nrendo.2009.106)

Feldberg W \& Lewis GP 1964 The action of peptides on the adrenal medulla Release of adrenaline by bradykinin and angiotensin. Journal of Physiology 171 98-108.

de Gasparo M, Catt KJ, Inagami T, Wright JW \& Unger T 2000 International union of pharmacology. XXIII. The angiotensin II receptors. Pharmacological Reviews 52 415-472.

Guo DF, Uno S \& Inagami T 1995 Steroid hormones upregulate rat angiotensin II type $1 \mathrm{~A}$ receptor gene: role of glucocorticoid responsive elements in rat angiotensin II type 1A promoter. Journal of Steroid Biochemistry and Molecular Biology 53 69-73. (doi:10.1016/09600760(95)00023-S)

Hamelink C, Tjurmina O, Damadzic R, Young WS, Weihe E, Lee HW \& Eiden LE 2002 Pituitary adenylate cyclase-activating polypeptide is a sympathoadrenal neurotransmitter involved in catecholamine regulation and glucohomeostasis. PNAS 99 461-466. (doi:10.1073/pnas.012608999)
Heemskerk FM \& Saavedra JM 1995 Quantitative autoradiography of angiotensin II AT2 receptors with $\left[{ }^{125} \mathrm{I}\right] \mathrm{CGP}$ 42112. Brain Research 677 29-38. (doi:10.1016/0006-8993(95)00092-5)

Henrion D 2012 Why do we need a selective angiotensin II type 2 receptor agonist? Hypertension 60 616-617. (doi:10.1161/HYPERTENSIONAHA. 112.197046)

Ichiki T, Kambayashi Y \& Inagami T 1996 Transcription of the rat angiotensin II type 2 receptor gene. Biochemical and Biophysical Research Communications 222 566-571. (doi:10.1006/bbrc.1996.0784)

Inagami T, Guo DF \& Kitami Y 1994 Molecular biology of angiotensin II receptors: an overview. Journal of Hypertension. Supplement: Official Journal of the International Society of Hypertension 12 S83-S94.

Israel A, Strömberg C, Tsutsumi K, Garrido MR, Torres M \& Saavedra JM 1995 Angiotensin II receptor subtypes and phosphoinositide hydrolysis in rat adrenal medulla. Brain Research Bulletin 38 441-446. (doi:10.1016/0361-9230(95)02011-F)

Jezova M, Armando I, Bregonzio C, Yu ZX, Qian S, Ferrans VJ, Imboden H \& Saavedra JM 2003 Angiotensin II AT(1) and AT(2) receptors contribute to maintain basal adrenomedullary norepinephrine synthesis and tyrosine hydroxylase transcription. Endocrinology 144 2092-2101. (doi:10.1210/en.2002-0019)

Jindra A \& Kvetnanský R 1982 Stress-induced activation of inactive renin. Molecular weight aspects. Journal of Biological Chemistry 257 5997-5999.

Jones ES, Vinh A, McCarthy CA, Gaspari TA \& Widdop RE 2008 AT2 receptors: functional relevance in cardiovascular disease. Pharmacology $\&$ Therapeutics 120 292-316. (doi:10.1016/j.pharmthera.2008.08.009)

Kijima K, Matsubara H, Murasawa S, Maruyama K, Mori Y \& Inada M 1995 Gene transcription of angiotensin II type 2 receptor is repressed by growth factors and glucocorticoids in PC12 cells. Biochemical and Biophysical Research Communications 216 359-366. (doi:10.1006/bbrc. 1995.2632)

Kvetnansky R \& Mikulaj L 1970 Adrenal and urinary catecholamines in rats during adaptation to repeated immobilization stress. Endocrinology 87 738-743. (doi:10.1210/endo-87-4-738)

Kvetnansky R, Kubovcakova L, Tillinger A, Micutkova L, Krizanova O \& Sabban EL 2006 Gene expression of phenylethanolamine $\mathrm{N}$-methyltransferase in corticotropin-releasing hormone knockout mice during stress exposure. Cellular and Molecular Neurobiology 26 735-754. (doi:10.1007/ s10571-006-9063-7)

Kvetnansky R, Sabban EL \& Palkovits M 2009 Catecholaminergic systems in stress: structural and molecular genetic approaches. Physiological Reviews 89 535-606. (doi:10.1152/physrev.00042.2006)

Leong DS, Terrón JA, Falcón-Neri A, Armando I, Ito T, Jöhren O, Tonelli LH, Hoe KL \& Saavedra JM 2002 Restraint stress modulates brain, pituitary and adrenal expression of angiotensin II AT(1A), AT(1B) and AT(2) receptors. Neuroendocrinology 75 227-240. (doi:10.1159/000054714)

Liu X, Kvetnansky R, Serova L, Sollas A \& Sabban EL 2005 Increased susceptibility to transcriptional changes with novel stressor in adrenal medulla of rats exposed to prolonged cold stress. Brain Research. Molecular Brain Research 141 19-29. (doi:10.1016/j.molbrainres.2005.07.019)

Liu X, Serova L, Kvetnanský R \& Sabban EL 2008 Identifying the stress transcriptome in the adrenal medulla following acute and repeated immobilization. Annals of the New York Academy of Sciences 1148 1-28. (doi:10.1196/annals.1410.082)

Martin MM \& Elton TS 1995 The sequence and genomic organization of the human type 2 angiotensin II receptor. Biochemical and Biophysical Research Communications 209 554-562. (doi:10.1006/bbrc.1995.1537)

McEwen BS 1998 Protective and damaging effects of stress mediators. New England Journal of Medicine 338 171-179. (doi:10.1056/ NEJM199801153380307)

McEwen BS 2007 Physiology and neurobiology of stress and adaptation: central role of the brain. Physiological Reviews 87 873-904. (doi:10.1152/ physrev.00041.2006)

McEwen BS \& Seeman T 1999 Protective and damaging effects of mediators of stress. Elaborating and testing the concepts of allostasis and allostatic load. Annals of the New York Academy of Sciences 896 30-47. (doi:10.1111/j.17496632.1999.tb08103.x) 
McMahon A \& Sabban EL 1992 Regulation of expression of dopamine $\beta$-hydroxylase in PC12 cells by glucocorticoids and cyclic AMP analogues. Journal of Neurochemistry 59 2040-2047. (doi:10.1111/j.1471-4159.1992. tb10092.x)

McMahon A, Kvetnansky R, Fukuhara K, Weise VK, Kopin IJ \& Sabban EL 1992 Regulation of tyrosine hydroxylase and dopamine $\beta$-hydroxylase mRNA levels in rat adrenals by a single and repeated immobilization stress. Journal of Neurochemistry 58 2124-2130. (doi:10.1111/j.1471-4159.1992. tb10954.x)

Muglia L, Jacobson L, Dikkes P \& Majzoub JA 1995 Corticotropin-releasing hormone deficiency reveals major fetal but not adult glucocorticoid need. Nature 373 427-432. (doi:10.1038/373427a0)

Muglia LJ, Jacobson L, Luedke C, Vogt SK, Schaefer ML, Dikkes P, Fukuda S, Sakai Y, Suda T \& Majzoub JA 2000 Corticotropin-releasing hormone links pituitary adrenocorticotropin gene expression and release during adrenal insufficiency. Journal of Clinical Investigation 105 1269-1277. (doi:10.1172/JCI5250)

Murasawa S, Matsubara H, Kanasaki M, Kijima K, Maruyama K, Nio Y, Okubo N, Tsukaguchi H, Mori Y \& Inada M 1995 Characterization of glucocorticoid response element of rat angiotensin II type 1A receptor gene. Biochemical and Biophysical Research Communications 209 833-840. (doi:10.1006/bbrc.1995.1575)

Murasawa S, Matsubara H, Kijima K, Maruyama K, Ohkubo N, Mori Y, Iwasaka T \& Inada M 1996 Down-regulation by cAMP of angiotensin II type 2 receptor gene expression in PC12 cells. Hypertension Research 19 271-279. (doi:10.1291/hypres.19.271)

Nankova B, Kvetnansky R, McMahon A, Viskupic E, Hiremagalur B, Frankle G, Fukuhara K, Kopin IJ \& Sabban EL 1994 Induction of tyrosine hydroxylase gene expression by a nonneuronal nonpituitarymediated mechanism in immobilization stress. PNAS 91 5937-5941. (doi:10.1073/pnas.91.13.5937)

Nishimura Y, Ito T, Hoe K \& Saavedra JM 2000 Chronic peripheral administration of the angiotensin II AT(1) receptor antagonist candesartan blocks brain AT(1) receptors. Brain Research 871 29-38. (doi:10.1016/ S0006-8993(00)02377-5)

Rauschkolb EW, Farrell GL \& Koletsky S 1956 Aldosterone secretion after hypophysectomy. American Journal of Physiology 184 55-58.

Remuzzi A, Malanchini B, Battaglia C, Bertani T \& Remuzzi G 1996 Comparison of the effects of angiotensin-converting enzyme inhibition and angiotensin II receptor blockade on the evolution of spontaneous glomerular injury in male MWF/Ztm rats. Experimental Nephrology 4 19-25.

Saavedra JM 2012 Angiotensin II AT(1) receptor blockers ameliorate inflammatory stress: a beneficial effect for the treatment of brain disorders. Cellular and Molecular Neurobiology 32 667-681. (doi:10.1007/s10571-0119754-6)

Saavedra JM, Armando I, Terrón JA, Falcón-Neri A, Jöhren O, Häuser W \& Inagami T 2001 Increased AT(1) receptors in adrenal gland of AT(2) receptor gene-disrupted mice. Regulatory Peptides 102 41-47. (doi:10.1016/ S0167-0115(01)00303-2)

Saavedra JM, Sánchez-Lemus E \& Benicky J 2011 Blockade of brain angiotensin II AT1 receptors ameliorates stress, anxiety, brain inflammation and ischemia: therapeutic implications. Psychoneuroendocrinology 36 1-18. (doi:10.1016/j.psyneuen.2010.10.001)
Sabban EL \& Kvetnanský R 2001 Stress-triggered activation of gene expression in catecholaminergic systems: dynamics of transcriptional events. Trends in Neurosciences 24 91-98. (doi:10.1016/S0166-2236(00)01687-8)

Sabban EL, Maharjan S, Nostramo R \& Serova LI 2010 Divergent effects of estradiol on gene expression of catecholamine biosynthetic enzymes. Physiology \& Behavior 99 163-168. (doi:10.1016/j.physbeh. 2009.07.011)

Serova L, Nankova B, Rivkin M, Kvetnansky R \& Sabban EL 1997 Glucocorticoids elevate GTP cyclohydrolase I mRNA levels in vivo and in PC12 cells. Brain Research. Molecular Brain Research 48 251-258. (doi:10.1016/S0169-328X(97)00098-3)

Serova LI, Nostramo R, Veerasirikul M, Cappell DB \& Sabban EL 2011 Varied mechanisms of oestradiol-mediated regulation of dopamine $\beta$-hydroxylase transcription. Journal of Neuroendocrinology 23 168-176. (doi:10.1111/j.1365-2826.2010.02086.x)

Stachowiak MK, Hong JS \& Viveros OH 1990a Coordinate and differential regulation of phenylethanolamine $\mathrm{N}$-methyltransferase, tyrosine hydroxylase and proenkephalin mRNAs by neural and hormonal mechanisms in cultured bovine adrenal medullary cells. Brain Research 510 277-288. (doi:10.1016/0006-8993(90)91378-T)

Stachowiak MK, Jiang HK, Poisner AM, Tuominen RK \& Hong JS $1990 b$ Short and long term regulation of catecholamine biosynthetic enzymes by angiotensin in cultured adrenal medullary cells. Molecular mechanisms and nature of second messenger systems. Journal of Biological Chemistry 265 4694-4702.

Stier CT, Serova LI, Singh G \& Sabban EL 2004 Stress triggered rise in plasma aldosterone is lessened by chronic nicotine infusion. European Journal of Pharmacology 495 167-170. (doi:10.1016/j.ejphar.2004.05.030)

Stroth N \& Eiden LE 2010 Stress hormone synthesis in mouse hypothalamus and adrenal gland triggered by restraint is dependent on pituitary adenylate cyclase-activating polypeptide signaling. Neuroscience $1651025-1030$. (doi:10.1016/j.neuroscience.2009.11.023)

Takekoshi K, Ishii K, Isobe K, Nanmoku T, Kawakami Y \& Nakai T 2000 Angiotensin-II subtype 2 receptor agonist (CGP-42112) inhibits catecholamine biosynthesis in cultured porcine adrenal medullary chromaffin cells. Biochemical and Biophysical Research Communications 272 544-550. (doi:10.1006/bbrc.2000.2821)

Takekoshi K, Ishii K, Shibuya S, Kawakami Y, Isobe K \& Nakai T 2002 Angiotensin II type 2 receptor counter-regulates type 1 receptor in catecholamine synthesis in cultured porcine adrenal medullary chromaffin cells. Hypertension 39 142-148. (doi:10.1161/hy1201.096816)

Wang DH, Qiu J \& Hu Z 1998 Differential regulation of angiotensin II receptor subtypes in the adrenal gland: role of aldosterone. Hypertension 32 65-70. (doi:10.1161/01.HYP.32.1.65)

Yang G, Xi ZX, Wan Y, Wang H \& Bi G 1993 Changes in circulating and tissue angiotensin II during acute and chronic stress. Biological Signals 2 166-172. (doi:10.1159/000109488)

Received in final form 16 August 2012

Accepted 21 August 2012

Made available online as an Accepted Preprint 21 August 2012 